\title{
Financial Performance of Retail Industry Before and After E-Commerce Booming in Indonesia: A Study of Altman Z-Score Model
}

\author{
Siti Rochmah Ika \\ Department of Accounting \\ Faculty of Economics and Business, Janabadra University \\ Yogyakarta, Indonesia \\ ika@janabadra.ac.id
}

Fami Nursiningsih

Department of Accounting

Faculty of Economics and Business, Janabadra University

Yogyakarta, Indonesia

Fami.nursi@gmail.com

\author{
Henry Sarnowo \\ Department of Economic Development \\ Faculty of Economics and Business, Janabadra University \\ Yogyakarta, Indonesia \\ henrysarnowo@janabadra.ac.id
}

\author{
Sahadi \\ Department of Civil Engineering \\ Faculty of Engineering, Janabadra University \\ Yogyakarta, Indonesia \\ sahadihadi5@janabadra.ac.id
}

\begin{abstract}
In recent years, many modern retail outlets are reported to close down their operation due to the financial downturn. Changes in a shopping behavior pattern that consumers prefer shopping online were blamed for the closure of the store. This article aims to examine whether there is any difference in the performance of the retail industry before and after e-commerce booming in companies listed on the Indonesia Stock Exchange. This study observes the financial statement of the industry in the period 2013-2017 using the Altman z- score model where 2015 onward represents the period of E-commerce booming. The descriptive statistic results indicate that $\mathrm{Z}$-Score after the e-commerce boom is lower than those in the period before the e-commerce boom on average. However, the results of the Wilcoxon signed rank-test showed that the performance of sample companies before and after the e-commerce boom did not show a significant difference. This article may give insight into the impact of online shopping booming on the financial performance of the retail store.
\end{abstract}

Keywords: financial performance, retail industry, e-commerce, Z score Altman

\section{INTRODUCTION}

A prospective new segment has grown in the Indonesian retail industry over the last few years. The new segment is called e-commerce as an addition to conventional markets and modern retail stores. It has been getting bigger and becoming an important retail segment specifically in the "lockdown" era due to spreading disease.

In 2015 investment in the e-commerce sector reached US\$19 million according to the Indonesia Investment Coordinating Board (BKPM) [1]. In terms of project operation, investments increased from 65 in 2014 to 67 in 2015. In the first half of 2016, e-commerce investment amounted to $\$ 5$ million, which include 24 operations. Many local e-commerce brands like Lazada.com, Tokopedia.com and Shopee.com are quickly gaining the public's trust, contributing to higher transaction value.

Owing to their tremendous growth potential, many international investors have concentrated on local e-commerce players. For example, Lazada.com was acquired by Alibaba.com at $\$ 1$ billion, and Tokopedia.com received \$247 million in investment funding from a variety of investors, including Softbank and Sequoia Capital [2]. Many estimate that in the next four years, e-commerce will take on $20 \%$ of the share in retail Indonesia. Currently, only 5\% of all domestic retail sales are in digital retail. The Minister of Communication and Informatics $\mathrm{Mr}$ Rudiantara says ecommerce booming starts in 2015 and expects to grow and reach USD 20 billion in the transaction values in 2016 [1] This optimism is encouraged by the massive number of internet and smartphone users in the country. According to SingPost, a worldwide logistics company, 5.9 million people made online transactions in Indonesia in 2015. The Indonesian E-commerce Group, meanwhile, predicts domestic ecommerce payments to triple from US\$ 8 billion in 2014 to US\$ 25 billion in 2016 [1].

The shine, bright, and increasing trend of e-commerce is likely to be opposite with the trend of offline stores. Several large modern retail outlets have announced their stores' closure in the last few years. HERO, for example, has closed at least 32 retail outlets after previously closing 26 Hero Supermarket outlets. In fact, the closure of retail outlets under HERO occurred several years ago. In 2018, HERO owned 445 outlets consisting of 82 Giant Express outlets, 57 Giant Extras, 3 Giant Marts, 32 Heroes, 270 Guardian, and 1 IKEA outlet. This figure is down compared to 2017, where the company has 449 outlets. In 2015, the number of HERO outlets had touched $610[3]$. 
Judging by HERO's finances, the company's total revenue has sloped since 2016. The company's revenue growth started to be negative until it reached its lowest point in 2018, with a total value of IDR 12.97 trillion [4]. In fact, in previous years HERO has always scored double-digit revenue growth and touched IDR 14.35 trillion in 2015.

The similar condition also faced by HERO's closest competitor, namely PT Matahari Putra Prima Tbk. (MPPA). The number of outlets of the retail company under the auspices of the Lippo Group has also declined in the last three years [3]. The number of MPPA outlets in 2018 was 219 outlets consisting of 107 Hypermart outlets, 24 Foodmart, 74 Boston, 12 Foodmart Xpress, and 2 Smartclubs. This figure has also decreased compared to 2017, which was 259 outlets, and 2016 as many as 299 outlets. In the past two years, MPPA closed at least 80 outlets.

The present study aims to examine whether there is any difference in the performance of the retail industry before and after e-commerce booming in companies listed on the Indonesia Stock Exchange (IDX). The study uses Altman distress prediction model [5] to assess the financial performance of the retail companies. Financial statements from 2013 to 2014 represent the period before e-commerce booming while those in 2015-2017 represent the period after e-commerce booming.

There are some studies which investigate the financial performance or financial distress of retail industry, for example [6] in the United Kingdom (UK), [7] in the United States (US) retail-apparel industry, [8] In the US high-low net operating income retail industry, and [9] also in the US due to the adoption of e-business in the company. Those studies use a variety of techniques to assess performance. [7] for example, use data envelopment analysis, [6], [9] utilize a set of financial ratios, while [8] use Du Pont model, [10] utilize Altman's model.

As stated earlier, the present study attempts to analyze whether the massive increased of e-commerce buyer would affect the financial performance of the retail industry. This study posits that after e-commerce booming, the financial performance of retail companies is worse than those in the period before booming. Given the fact that the majority of retail companies listed on IDX are offline seller, the increase of internet user in the country combined with the convenience of online shopping platforms would impact on the lower sales revenue. Such condition is different than those in [9] study where the sample is the early adopter of e-business in the retail industry.

There are also some studies which use Altman $\mathrm{Z}$ score to predict bankruptcy, for example [10]-[12]. However, to the best of author knowledge, none of previous studies or minimum if there is any which specifically investigate the financial performance of the retail industry due to the ecommerce booming. Therefore, this present study seeks to fill this gap.

\section{METHOD}

\section{A. Population, Sampling, and Sample}

The population of the study is the twenty-five companies listed on IDX in the retail industry in the period 2013-2017. This study uses purposive sampling to choose the sample based on the following criteria. First, the company publicize annual report in the period 2013-2017, and the report is available. Second, the report contains complete data related to the research variable. There are eighteen companies suitable for the above criteria. The list of the sample is provided here due to the need of company name in the discussion section. The list is as follow. (1) PT Sumber Alfaria Trijaya Tbk (AMRT), (2) PT Ace Hardware Indonesia Tbk (ACES), (3) PT Matahari Departement Store Tbk (LPPF), (4) PT Mitra Adiperkasa Tbk (MAPI), (5) PT Ramayana Lestari Sentosa Tbk (RALS), (6) PT Erajaya Swasembada Tbk (ERAA), (7) PT Tiphone Mobile Indonesia Tbk (TELE), (8) PT Trikomsel Oke Tbk (TRIO), (9) PT Matahari Putra Prima Tbk (MPPA), (10) PT Skybee Tbk (SKYB), (11) PT Electronic City Indonesia Tbk (ECII), (12) PT Global Teleshop Tbk (GLOB), (13) PT Supra Boga Lestari Tbk (RANC), (14) PT Catur Sentosa Adiprana Tbk (CSAP), (15) PT Hero Supermarket Tbk (HERO), (16) PT Kokoh Inti Arebama Tbk (KOIN), (17) PT Midi Utama Indonesia Tbk (MIDI), (18) PT Sona Topas Tourism Industry Tbk (SONA).

\section{B. Data}

Data were obtained from the company's annual report or audited annual financial statement that available on the IDX website, company's website, or IDN financials' website (www.idnfinancials.com).

\section{Financial Performance Measurement}

To evaluate the performance of the sample companies, this study uses Altman's Z-score bankruptcy model [5]. Altman's $\mathrm{Z}$ is one of the best known statistically-based predictive models for predicting the imminent bankruptcy of a company [10]. The equitation is presented as follow.

$$
\mathrm{Z}=1.2 \mathrm{X}_{1}+1.4 \mathrm{X}_{2}+3.3 \mathrm{X}_{3}+0.6 \mathrm{X}_{4}+1.0 \mathrm{X}_{5}
$$

Where

$$
\begin{aligned}
& \mathrm{X}_{1}=\text { working capital / total asset } \\
& \mathrm{X}_{2}=\text { retained earnings } / \text { total asset } \\
& \mathrm{X}_{3}=\text { earnings before interest and taxes / total asset } \\
& \mathrm{X}_{4}=\text { market capitalization / book value of debt } \\
& \mathrm{X}_{5}=\text { sales / total asset }
\end{aligned}
$$

According to [5], the higher the Z-score, the better the financial performance of the company. The classification of the $\mathrm{Z}$ score is as follow.

If $\mathrm{Z}>2.99$, the company is not distress or financially healthy.

If $\mathrm{Z}=1.81$ to 2.99 , the company is included in the grey area.

If $Z<1.81$, the company is financially distressed. 


\section{Data Analysis Technique}

To examine whether there is any difference in the Z-score in the period before and after e-commerce booming, the present study utilizes the Wilcoxon Signed Rank Test. The year 2015 is the period of e-commerce booming starts. It is based on the data gathered and the statement of The Minister of Communication and Informatics, $\mathrm{Mr}$ Rudiantara, as explained in the introduction section. Therefore, the Z-score during 2013-2014 represents the period before and the year 2015-2017 represents the period after e-commerce booming.

\section{RESULTS AND DISCUSSION}

\section{A. Statistic Descriptive}

TABLE I. DESCRIPTIVE STATISTIC OF THE Z-SCORE

\begin{tabular}{|c|c|c|c|c|c|c|}
\hline No & Code & 2013 & 2014 & 2015 & 2016 & 2017 \\
\hline 1 & AMRT & 3.72 & 3.55 & 3.97 & 3.44 & 3.25 \\
\hline 2 & ACES & 5.56 & 6.22 & 6.24 & 6.41 & 5.97 \\
\hline 3 & LPPF & 5.22 & 5.55 & 5.99 & 5.64 & 5.21 \\
\hline 4 & MAPI & 2.07 & 2.33 & 2.22 & 2.21 & 2.44 \\
\hline 5 & RALS & 6.49 & 5.78 & 5.66 & 5.78 & 5.60 \\
\hline 6 & ERAA & 4.26 & 3.72 & 3.57 & 3.99 & 3.88 \\
\hline 7 & TELE & 4.37 & 4.56 & 4.93 & 5.28 & 5.09 \\
\hline 8 & TRIO & 2.56 & 2.72 & -45.22 & -35.11 & -36.94 \\
\hline 9 & MPPA & 3.39 & 3.97 & 3.45 & 2.87 & 1.25 \\
\hline 10 & SKYB & 2.12 & 2.70 & -1.27 & -2.27 & 21.31 \\
\hline 11 & ECII & 5.28 & 7.05 & 9.51 & 8.54 & 7.49 \\
\hline 12 & GLOB & 3.91 & 3.35 & -23.62 & -17.36 & -17.11 \\
\hline 13 & RANC & 3.29 & 3.20 & 3.63 & 4.53 & 4.31 \\
\hline 14 & CSAP & 2.60 & 2.82 & 2.60 & 2.63 & 2.48 \\
\hline 15 & HERO & 3.80 & 3.24 & 3.43 & 4.07 & 3.56 \\
\hline 16 & KOIN & 5.74 & 3.20 & 4.07 & 3.64 & 3.63 \\
\hline 17 & MIDI & 2.78 & 2.89 & 2.76 & 2.50 & 2.34 \\
\hline 18 & SONA & 3.55 & 3.58 & 3.69 & 3.15 & 3.40 \\
\hline \multicolumn{2}{|r|}{ Mean } & 3.93 & 3.91 & -0.24 & 0.55 & 1.51 \\
\hline \multicolumn{2}{|r|}{ Min } & 2.07 & 2.33 & -45.22 & -35.11 & -36.94 \\
\hline \multicolumn{2}{|r|}{ Max } & 6.49 & 7.05 & 9.51 & 8.54 & 21.31 \\
\hline
\end{tabular}

Table I shows the descriptive statistics of the Z-score value of the sample companies in the period before the e-commerce boom (2013-2014) and after the e-commerce boom (20152017). The average $Z$-score before the e-commerce boom was around 3.9, which means the companies are financially healthy. Meanwhile, the average Z-score in the period after the e-commerce boom was $-0.24,0.55$, and 1.51 in 2015, 2016 and 2017, respectively. According to the Altman Z-score classification, the companies' financial condition is bankrupt. Table I suggests that the Z-score dropped dramatically after the e-commerce boom as compared to those in the period before.

The lowest z-score was obtained by MAPI at 2.07 and 2.33 in 2013 and 2014 respectively. The Z-score indicates that the company's financial condition is in the grey area. MAPI is a company that sells world-famous brands, such as Zara, Swatch, Lotus, Sogo, Adidas, Reebok, Calvin Klein,
Converse, Sports Station, and Starbucks. In the period after the e-commerce boom, the minimum Z-score was negative, i.e. $-45.22,-35.11$, and -36.94 in 2015, 2016 and 2017 respectively. The lowest Z-score was consistently obtained by TRIO, a company that sells various types of telecommunication equipment, cellular phone and its accessories. These numbers indicate the company's financial condition is distressed. In other words, in the period after the e-commerce boom, the company faces bankruptcy as suggested by the negative value of $\mathrm{Z}$-score.

Meanwhile, the highest Z-score in the period before the ecommerce boom was obtained by RALS in 2013 (6.49) and ECII (7.05) in 2014. RALS is a fashion retail company famous with Ramayana brand, while ECII is an electronic goods selling company called Electronic City. The Z-score of the two companies indicates the companies are financially healthy.

The highest Z-score in the period after the e-commerce boom also shows that the company is in a healthy condition. The maximum Z-scores in 2015 and 2016 were 9.51 and 8.54 respectively. The ECII has consistently obtained these values. Whereas in 2017, the highest Z-score was obtained by SKYB (21.31). SKYB is a seller of multimedia hardware and software, telco link, content and applications. Whereas in the previous year the Z-score SKYB was negative. This is because SKYB in 2017 managed to restructure its debt.

The following Table II presents the overall average Zscore in the period before and after the e-commerce boom

TABLE II. THE AVERAGE Z-SCORE BEFORE AND AFTER E-COMMERCE BOOM

\begin{tabular}{|c|c|c|c|}
\hline No. & Code & $\begin{array}{c}\text { Mean Z-score } \\
\text { before } e \text {-commerce } \\
\text { boom } \\
(2013-2014)\end{array}$ & $\begin{array}{c}\text { Mean Z-score } \\
\text { after } e \text {-commerce } \\
\text { boom } \\
(2015-2017)\end{array}$ \\
\hline 1 & AMRT & 3.64 & 3.55 \\
\hline 2 & ACES & 5.89 & 6.21 \\
\hline 3 & LPPF & 5.39 & 5.61 \\
\hline 4 & MAPI & 2.20 & 2.29 \\
\hline 5 & RALS & 6.14 & 5.68 \\
\hline 6 & ERAA & 3.99 & 3.81 \\
\hline 7 & TELE & 4.47 & 5.10 \\
\hline 8 & TRIO & 2.64 & -39.09 \\
\hline 9 & MPPA & 3.68 & 2.52 \\
\hline 10 & SKYB & 2.41 & 5.92 \\
\hline 11 & ECII & 6.17 & 8.51 \\
\hline 12 & GLOB & 3.63 & -19.36 \\
\hline 13 & RANC & 3.25 & 4.16 \\
\hline 14 & CSAP & 2.71 & 2.57 \\
\hline 15 & HERO & 3.52 & 3.69 \\
\hline 16 & KOIN & 4.47 & 3.78 \\
\hline 17 & MIDI & 2.84 & 2.53 \\
\hline 18 & SONA & 3.57 & 3.41 \\
\hline \multicolumn{2}{|r|}{ Mean } & 3.92 & 0.61 \\
\hline \multicolumn{2}{|r|}{ Min } & 2.20 & -39.09 \\
\hline \multicolumn{2}{|r|}{ Max } & 6.14 & 8.51 \\
\hline
\end{tabular}


As can be seen in Table II, the average Z-score for the period before the e-commerce boom was higher than those after the e-commerce boom (3.92 versus 0.61). The interpretation of the results is the same as that shown in Table I. The decrease in the mean Z-Score value is contributed by TRIO and GLOB which come up with highly negative Z-score values, i.e. -39.09 and -19.36 by TRIO and GLOB respectively. The Z-score data of the two companies potentially to become outliers. Therefore, Table III seeks to present the Z-score with the exception of TRIO and GLOB in the list.

TABLE III. THE AVERAGE Z-SCORE BEFORE AND AFTER E-COMMERCE BOOM WITHOUT TRIO AND GLOB

\begin{tabular}{|c|c|c|c|}
\hline No. & Code & $\begin{array}{c}\text { Mean Z-score } \\
\text { before } \text {-commerce } \\
\text { booming } \\
\mathbf{( 2 0 1 3 - 2 0 1 4 )}\end{array}$ & $\begin{array}{c}\text { Mean Z-score } \\
\text { after } \text {-commerce } \\
\text { Booming } \\
\mathbf{( 2 0 1 5 - 2 0 1 7 )}\end{array}$ \\
\hline 1 & AMRT & 3.64 & 3.55 \\
\hline 2 & ACES & 5.89 & 6.21 \\
\hline 3 & LPPF & 5.39 & 5.61 \\
\hline 4 & MAPI & 2.20 & 2.29 \\
\hline 5 & RALS & 6.14 & 5.68 \\
\hline 6 & ERAA & 3.99 & 3.81 \\
\hline 7 & TELE & 4.47 & 5.10 \\
\hline 8 & MPPA & 3.68 & 2.52 \\
\hline 9 & SKYB & 2.41 & 5.92 \\
\hline 10 & ECII & 6.17 & 8.51 \\
\hline 11 & RANC & 3.25 & 4.16 \\
\hline 12 & CSAP & 2.71 & 2.57 \\
\hline 13 & HERO & 3.52 & 3.69 \\
\hline 14 & KOIN & 4.47 & 3.78 \\
\hline 15 & MIDI & 2.84 & 2.53 \\
\hline 16 & SONA & 3.57 & 3.41 \\
\hline & Mean & 4.02 & 4.33 \\
\hline & Min & 2.20 & 2.29 \\
\hline & Max & 6.17 & \\
\hline
\end{tabular}

As can be seen in Table III after TRIO (PT Trikomsel Oke Tbk) and GLOB (PT Global Teleshop) were removed from the sample, the average Z-Score before and after the e-commerce boom was almost the same. Specifically, the number increases from 4.02 to 4.33. According to the Altman classification, they are financially healthy. The same pattern applies to the minimum and maximum values in the table whereby the $\mathrm{Z}$ score slightly increases in the period after the e-commerce boom. The results imply that with the booming e-commerce, the retail industry companies manage to perform their finances.

\section{B. Mean Difference Test}

Table IV presents the results of the Wilcoxon sign rank test for the Z-score of the sample companies. This test still includes TRIO and GLOB as samples. The Wilcoxon test was carried out several times, namely on the overall mean of the period before and after the e-commerce boom and year on year before and after the e-commerce boom.

As shown in Table IV, the sig value of Wilcoxon sign rank test on the overall mean before and after the e-commerce boom and year on year testing is above 0.05 . The results suggest that the decrease in the Z-score in the period after the e-commerce boom is not statistically significant as compared to those in the period before. In other words, there is no difference in the Z-score of retail companies before and after the e-commerce boom. The results also imply that the drastic decrease in the mean Z-score does not affect the results of the difference test.

TABLE IV. RESUlt OF WILCOXON Sign RANK TEST

\begin{tabular}{|c|c|c|c|c|c|}
\hline No. & $\begin{array}{c}\text { Year } \\
\text { comparison }\end{array}$ & $\begin{array}{c}\text { Mean } \\
\text { before e- } \\
\text { commerce } \\
\text { boom }\end{array}$ & $\begin{array}{c}\text { Mean } \\
\text { after e- } \\
\text { commerce } \\
\text { boom }\end{array}$ & Z & Sig \\
\hline 1 & $\begin{array}{c}\text { All year before } \\
\text { and after }\end{array}$ & 3.92 & 0.61 & -0.327 & 0.744 \\
\hline 2 & 2014 and 2015 & 3.91 & -0.24 & -0.174 & 0.862 \\
\hline 3 & 2013 and 2015 & 3.93 & -0.24 & -0.639 & 0.523 \\
\hline 4 & 2014 and 2016 & 3.91 & 0.55 & -0.379 & 0.705 \\
\hline 5 & 2013 and 2016 & 3.93 & 0.55 & -0.871 & 0.384 \\
\hline
\end{tabular}

Figure 1 presents the Z-score trend of the sample firms during the observation period.

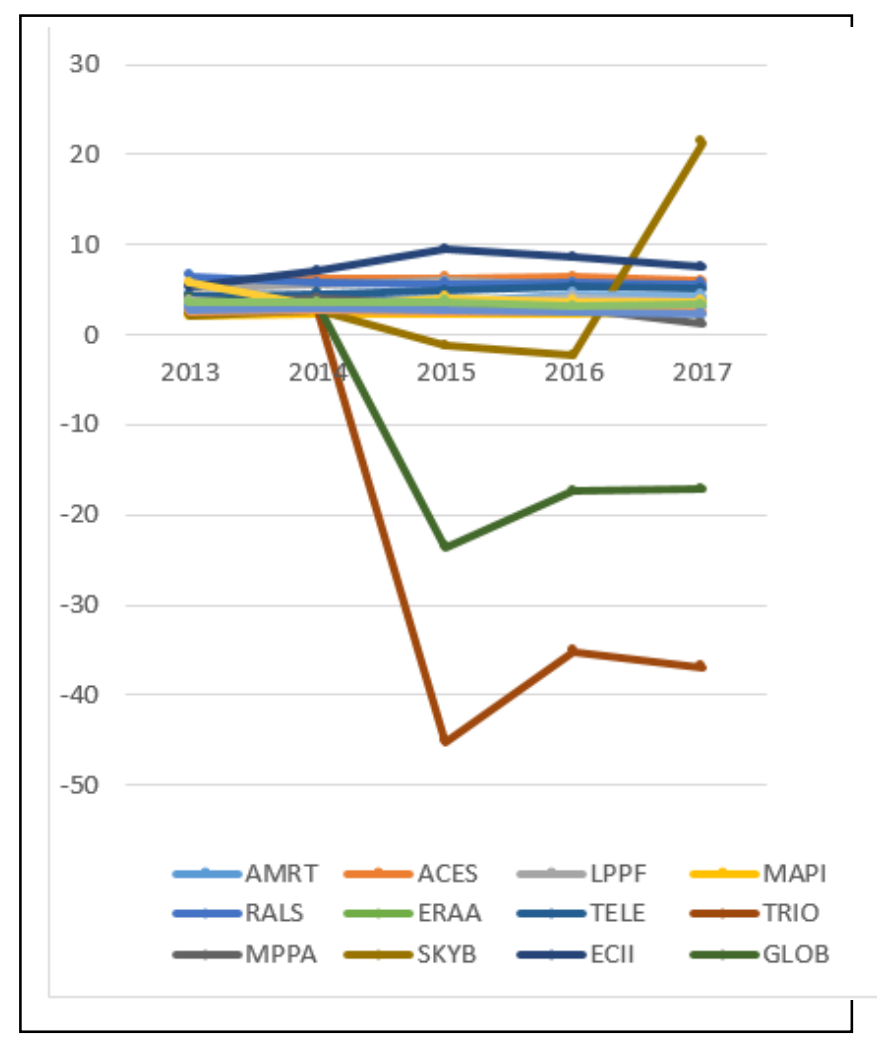

Fig. 1. The Trend of Z-score in the window period

As can be seen from the figure, the majority of sample firms have stable Z-core values during the observation period. The interpretation of the trend results is consistent with the results of the Wilcoxon signed-rank test. Two companies experienced a drastic drop in their Z-score, namely TRIO and GLOB. One company has a pattern of decline until 2016, then rose dramatically in 2017. 


\section{Discussion}

The descriptive statistics of the sample companies show that the Z-score value in the period before the e-commerce boom decreased compared to the post-boom period from 3.92 to 0.61 (Table II). There are two companies in the sample that the Z-score's dramatically decreased in the year 2015-2017. The two companies, namely TRIO and GLOB, are in the same business, i.e. selling cellular phones. This finding suggests that the e-commerce boom has had a major impact on the mobile phone sales outlet business. The plausible explanation is that the sales volume of cellular phones in the market places such as shopee and Lazada is also very high. Sellers at those market place provide competitive prices. According to [13], smartphone sales are the highest product sales category in Indonesian e-commerce after the fashion. Besides, the competition with small offline retails sellers is also getting fierce.

The results of the Wilcoxon sign rank test (Table IV) show that there is no difference in the Z-score before and after the ecommerce boom. The results suggest that the financial performance of the sample companies are stable. The plausible explanation is that in the midst of the onslaught of ecommerce in the retail industry, industry players who were originally offline are also selling online (omnichannel) to stay afloat and grow. As stated by Chairman of the Indonesian Retail Entrepreneurs Association (Aprindo) Roy N. Mandey, 95\% of Aprindo members have transformed and developed online sales. Example of the companies which also adapt to technology and digitalization by opening e-commerce in their sales, are HERO with its IKEA, and LPPF with Mataharimall.com. The finding is somewhat consistent [9], which states that companies who adopt e-business will have better financial performance ratios.

\section{CONCLUSION}

This study aims to examine whether there is any difference in the financial performance of retail companies in the period before and after the e-commerce boom. The Z-score after ecommerce boom decreased as compared to those in before boom; however, the difference is not statistically significant. The majority of companies in the retail industry have a stable Z-score except for two companies, namely TRIO and GLOB. The results may imply that the existing companies in the retail industry have been trying to adopt with digitalization and transforming or starting to develop online selling. This study only utilizes Altman Z-score [5] in measuring financial performance. There is other financial distress model that might be used to see the consistency, e.g. [14], [15]. Probably the next research may use these other bankruptcy prediction model.

\section{ACKNOWLEDGMENT}

The authors would like to thank the Faculty of Economics and Business for granting this research.

\section{REFERENCES}

[1]

Global Business Guide Indonesia, “Indonesia's Retail Sector; ECommerce, the Next Growth Driver," gbgindonesia.com, 2016. http://www.gbgindonesia.com/en/services/article/2016/indonesia_s_ retail_sector_e_commerce_the_next_growth_driver_11631.php.

H. Pratiwi, "Potensi dan Tantangan E-commerce Indonesia Tahun 2015," id.berita.yahoo.com, 2014 https://id.berita.yahoo.com/potensi-dan-tantangan-e-commerce014612068.html (accessed Sep. 05, 2019).

[3] N. H. Tamara, "Analisis Data: Perubahan Peta Persaingan Bisnis Retail di Indonesia," katadata.co.id, 2019. https://katadata.co.id/analisisdata/2019/07/03/perubahan-petapersaingan-bisnis-retail-di-indonesia (accessed Jul. 02, 2019).

[4] HERO Group, "HERO Annual Report 2018," Investment Report, 2018. https://www.hero.co.id/investor/publication (accessed Dec. 01, 2020)

[5] E. I. Altman, "Financial Ratios, Discriminant Analysis and the Prediction of Corporate Bankruptcy," J. Finance, vol. 23, no. 4, pp. 589-609, 1968

[6] J. Chenchehene and K. Mensah, "Corporate Survival: Analysis of Financial Distress and Corporate Turnaround of the UK Retail Industry," Int. J. Lib. Arts Soc. Sci., vol. 2, no. 9, pp. 18-34, 2014, [Online]. Available: www.ijlass.org.

[7] A. T. Kingyens, J. C. Paradi, and F. Tam, Bankruptcy prediction of companies in the retail-apparel industry using data envelopment analysis, vol. 249. 2016.

[8] P. L. Little, B. L. Little, and D. Coffee, "THE DU PONT MODEL: EVALUATING ALTERNATIVE STRATEGIES IN THE RETAIL INDUSTRY," Acad. Strateg. Manag. J., vol. 8, no. 1, pp. 71-80, 2009.

[9] L. F. Motiwalla and M. R. Khan, "Financial Impact of E-Business Initiatives in the Retail Industry," J. Electron. Commer. Organ., vol. 1, no. 1, pp. 55-73, 2003.

[10] S. K. Hayes, K. A. Hodge, and L. W. Hughes, "A Study of the Efficacy of Altman's Z To Predict Bankruptcy of Specialty Retail Firms Doing Business in Contemporary Times," Econ. Bus. J., vol. 3 , no. 1 , pp. 120-134, 2010.

[11] S. A. Sulub, "Testing the Predictive Power of Altman's Revised Z 'Model : The Case of 10 Multinational Companies," Res. J. Financ. Account., vol. 5, no. 21, pp. 174-185, 2014.

[12] B. A. Alareeni and J. Branson, "Predicting Listed Companies' Failure in Jordan Using Altman Models: A Case Study," Int. J. Bus. Manag., vol. 8, no. 1, 2012, doi: 10.5539/ijbm.v8n1p113.

[13] K. B. and B. L., "INDONESIA'S TOP 4 ECOMMERCE PRODUCT CATEGORIES,” Janio.asia, 2019. http://janio.asia/articles/indonesia-s-top-4-e-commerce-productcategories/.

[14] M. E. Zmijweski, "Methodological Issues Related to the Estimation of Financial Distress Prediction Models," J. Account. Res., vol. 22, pp. 59-82, 1984.

[15] G. L. Springate, "Predicting the Possibility of Failure in a Canadian Firm," Simon $\quad$ Fraser University, 1978. 